\title{
Structural patterns of internal migration flows in Botswana: log-linear modeling approach
}

\author{
P.S. Nair ${ }^{1}$ \\ and \\ T.M. Masukusuku \\ Department of Population Studies \\ University of Botswana \\ Gaborone
}

\section{Abstract}

Among the total population in Botswana, 40 percent are lifetime migrants and females exceed males. Movement from rural to urban areas dominates the pattern of internal migration. The log-linear modeling analysis, which provides parametric values for the inter-district effects, shows that the Central district has the highest push effect and Gaborone, Northeast and Francistown are the most attractive places of destination. The other districts which pulled migrants from Central are Towns and small towns. Next, Southern and Kweneng districts have the highest push effects. Gaborone, the capital city district, exhibited a significantly high mobility in terms of both inmigration and outmigration. Again, Gaborone has the highest column effect or pull factor, followed closely by the Central district. The interaction effects between districts are also shown vividly through log-linear parameters.

Keywords: Botswana, lifetime migration flows, log-linear modeling, structural patterns and preference index.

\section{Introduction}

In developing countries, internal migration accounts for a disproportionate share of the differential growth rates of urban and rural areas; and in locations where urban and rural fertility are very similar, it accounts for almost all of the differentials (UN, 1967). In the more developed nations, as the vital rates become more or less homogeneous between regions, migration becomes increasingly crucial in accounting for the differential growth rates and for changes in population composition. The importance of spatial mobility as a determinant of population dynamics, however, goes well beyond this. According to Goldstein (1976), "most, if not all, of the great social problems confronting both developed and less developed regions today probably have a migration component". No doubt what Goldstein stated more than three decades ago is still relevant in the contemporary world.

A glimpse over the migration literature available for sub-Saharan Africa is presented in the following paragraphs as a forerunner to the present analysis. Economic and political transitions in countries of Africa, Asia, Eastern

I. Address for correspondence: Prof. P.S. Nair, nairps@mopipi.ub.bw. 
Europe, Latin America and the Pacific have made migration a salient feature of life in developing and developed countries (Beauchemin and Bocquier, 2004; Massey et al. 1993; Todaro, 1997). In sub-Saharan Africa, migration studies have primarily focused on the relationships between migration, spatial redistribution, urbanization and development (Beauchemin and Bocquier, 2004, Bocquier, 2004, Bilsborrow, 1998; Oucho, 1998, 2006, Deborah P, 2009). On internal migration, there is particular focus on the selectivity of the young, the educated, the innovative and the energetic into rural-urban migration, which perpetuates rural poverty and dependency, undermines rural social viability and exacerbates unemployment and sub-optimal living standards in urban areas (Adepoju, 1983, 2004; Dijk et al., 200I; UN-HABITAT, 2003). Researchers have increasingly pointed to the vulnerability of migrants to adverse living conditions in their urban destinations in sub-Saharan Africa. In particular, persistent migration to urban areas in the context of declining economic performance of most African countries has been linked to a new face of poverty, with a significant proportion of population living below the poverty line in overcrowded slums and sprawling shanty towns around major cities (Brockerhoff, 1998; UN-HABITAT, 2003). On international migration, the focus in the region has been dominated by debates on the benefits for sending and receiving countries in terms of brain drain and gains, remittances and issues around asylum seekers and refugees, together with the recent rising cases of desperate and precarious migration of young people through uncharted routes, illegal immigration and human trafficking (Adepoju, 2005a, 2005b). What is generally lacking in the region are commensurate studies on migration as part of the livelihood and survival strategy for rural families, and the perspective that population redistribution and the growth of cities and towns are expected to serve as important catalysts for national development (Andersson, 200I; Gurmu et al., 2000). Apart from this, unfavourable government policies and poor governance often trigger movements, particularly of the most vulnerable poor. Furthermore, the disruptions associated with civil wars, recurring droughts, famines, political conflicts etc. complicate the model of migration both as a major component of population change and as a determinant or consequence of economic development (Adepoju, 1983; Mberu, 2006). Yet these contexts, which are typical of several African countries and relevant for a more balanced and comprehensive understanding of Africa's migration systems, remain scarcely examined.

The links between urbanization and migration in Francophone West Africa since the mid-1980s have been studied comprehensively (Beauchemin and Bocquier, 2004, Becker C.M., Hamer A.M., 1994). Based on this, they proposed to re-examine the contribution of migration to urbanization in the developing world. The contribution of migration to urbanization is examined from different points of view; demographic, geographic and economic. The conclusions are that migrants adapt quite well to the city and that urban integration problems do not concern exclusively migrants but all city-dwell- 
ers, especially the youth.

Many scholars have lamented the paucity and poor quality of data sources in developing countries, especially in Africa, which hampered the study of both international and internal migration. For instance, Oucho (2006) makes a useful comparison of the situation prevailing in southern African region vis-à-vis other regions of Africa. Although the southern African countries keep virtually similar administrative records, they hardly process the data to provide insights into immigration and emigration. If migration researchers shy away from utilizing existing data, they might not undertake rigorous analyses and they would simply be philosophizing about a phenomenon whose magnitude of stock and flows indisputably need to be revealed (Oucho, 2006), in particular the brain drain in the sub-region, skilled immigration to South Africa and Botswana (Oucho, 2002) and the brain drain from South Africa (Crush et al., 2000) and Zimbabwe.

According to many scholars ( for instance, Bilsborrow, 1998, Mberu, B. U. and Pongou, R. 2005) the dearth of data on migration and the limited focus on the structural conditions that motivate migration from specific localities within the region remain glaring in Africa and it underscores the need for substantial investment in data collection and management. Such a focus has great potential and holds out the promise for a more comprehensive evidence-based response, at the level of policy and programmes, in addressing in particular - the challenges of desperate and distressed migration that seem to have dominated Africa's migration systems in recent years.

Most of the migration studies in developing countries have focused on lifetime and period migration stocks rather than flows. No doubt, the four streams of internal migration have received some attention, especially the rural-urban migration due to its overriding importance on development. However, the studies on the stability of the structural patterns and their determinants of place to place gross migration flows still remain unexplored fully in developing world especially in the African region. The most glaring limitation is, perhaps, the absence of the use of any sophisticated methodology for analyzing the structural patterns of the migratory flows.

It is true that unlike fertility and mortality, there is a lack of sufficiently sophisticated theory and analytical tools for quantitative as well as qualitative analysis of spatial mobility. However, there has been a breakthrough in the realm of migration analysis since the last quarter of the $20^{\text {th }}$ century. More and more analytical techniques, which were the prerogatives of such disciplines as Physics, Regional Science, Mathematics and Statistics have emerged in the 'raw' or in adapted forms in migration analysis. A review of several such techniques and of data problems is available in the literature on migration (e.g. Willekens, 1977; 1983; Willekens and Nair, 198I). One such technique which can be used to examine the temporal stability of the structure of place-to-place gross migration flows is the log-linear model (see details later) which is increasingly employed in contingency table analysis. The application of log-linear model and the analysis of macro level migration 
data in directional flow matrix itself are significant developments especially for developing countries. Through the parameters of the model, we can identify and quantify the structural patterns, especially the push factors, pull factors as well as interaction effects between regions or places. While these factors or effects are identified, geographic distance and population size effects are accounted for, which, in turn, serves as a measure of standardization. Every migratory flow could be analyzed by disaggregating the overall size effect of the total flows, column (pull) factor, row (push) factor and the place- toplace interaction effect. Thus the loglinear modeling provides a comprehensive analysis of the patterns of migratory flows. Furthermore, availability of the parameters of the model helps a more meaningful comparison between countries or provinces within a country. These properties, perhaps, underscore the advantage for log-linear modeling vis-à-vis the conventional analysis in migration analysis. Nair (198I, 1985) had employed the technique for a detailed analysis of Indian and Sri Lankan data. However, although placeto-place migration flows are very significant nowadays in Africa, especially in southern Africa, there has not been any such analysis reportedly made in subSaharan Africa.

With this backdrop, an attempt has been made in this paper to use log-linear modeling approach in order to study the structural patterns of interdistrict migration flows over time in Botswana. The choice of the country is arbitrary for obvious reasons. However, the analytical rigour implied in the analysis could be replicated in other larger nations of the region for deriving more insights on the structural patterns of internal migration.

In order to place the present analysis in the right perspective, the log-linear analysis is preceded by a conventional analysis on the levels of inmigration, outmigration and net migration in Botswana in recent years. This will provide an idea on the additional insights we may gather from the log-linear modeling approach.

\section{Internal migration in Botswana: an overview}

Botswana remained a British protectorate until 1966. When the first national census of independent Botswana was conducted in 1971, the population stood at 0.6 million. It grew to 1.7 million in 200I and 2.0 million in 20I I(CSO, 20I I). In Sub-Saharan Africa, Botswana is well known on two counts; first as a fast growing economy due to a large reserve of diamonds and second, as a country with the highest prevalence rate of HIV/AIDS.

Unlike several neighboring countries in the region, Botswana has been a net immigrating country due to better living standards and a vibrant democratic system in the region. Botswana has been shown to benefit immensely from the immigration of skilled workers, notably doctors, nurses, teachers and university lecturers (Campbell, E.K and Oucho, J.O. 2003). Along with international migration, internal migration also has been quite rampant in the country relatively. The most recent data on internal migration shows that 40 percent of the population is life time migrants within Botswana (CSO, 2008). Around 3 percent of the total popula- 
tion was immigrants of which seventynine percent originated from Southern African countries. Among the internal migrants, females exceeded males, with the sex ratio being 0.91 . The dominance of females among internal migrants is not unexpected in Botswana as the country's sex ratio favours females.

\section{Urban and rural patterns}

Movement from rural to urban areas still dominates the patterns of internal migration in Botswana (CSO, 2008) as observed in many developing countries. Forty-five percent of all movements were from rural to urban areas. Urbanrural migration was a distant second (2I percent), followed by urban-urban migration stream. Rural-rural migration, which predominated prior to 1966 , is now at the lowest ebb of the migration patterns. Gaborone, the capital city, received the highest volume of inmigrants, both from rural and urban areas. (42 percent). More males undertook urban-rural movements than females (sex ratio $=1.068)$. Meanwhile, unlike many other developing countries, migration to urban areas was predominantly by females. Migration to urban areas generally reflects greater propensity towards maximizing personal developmental skills and quality of life. The sex differentials of migratory flows are, perhaps, an underlying factor in the remarkable socioeconomic development of women in Botswana since 1966 (CSO, 2008).

\section{Migration rates.}

Table I In-migrants and Out-migrants by District

\begin{tabular}{|c|c|c|c|c|c|c|c|}
\hline $\begin{array}{c}\text { District } \\
\text { (Census) of } \\
\text { Enumeration }\end{array}$ & $\begin{array}{c}\text { In- } \\
\text { Migrants }\end{array}$ & $\begin{array}{c}\text { Sex } \\
\text { Ratio }\end{array}$ & $\begin{array}{c}\text { Out- } \\
\text { Migrants }\end{array}$ & $\begin{array}{l}\text { In-m } \\
\text { rate } \\
\text { (Total) }\end{array}$ & $\begin{array}{c}\text { Male In- } \\
\text { migration } \\
\text { rate }\end{array}$ & $\begin{array}{c}\begin{array}{c}\text { Female } \\
\text { In- } \\
\text { migration } \\
\text { rate }\end{array} \\
\end{array}$ & $\begin{array}{c}\text { Out- } \\
\begin{array}{c}\text { migration } \\
\text { rate } \\
\text { (Total) }\end{array} \\
\end{array}$ \\
\hline Gaborone & $|25,95|$ & 0.94 & 6,626 & 8.66 & 8.71 & 8.62 & 3.79 \\
\hline Francistown & 48,248 & 0.95 & 1,599 & 3.11 & 3.14 & 3.08 & 2.07 \\
\hline Lobatse & 17,276 & 0.94 & 1,423 & 1.08 & 1.08 & 1.07 & 5.00 \\
\hline Selebi Phikwe & 29,100 & I.0I & $\mathrm{I}, 007$ & 1.84 & 1.92 & 1.76 & 2.24 \\
\hline Orapa & 11,656 & 0.84 & 537 & 0.72 & 0.69 & 0.76 & 3.84 \\
\hline Jwaneng & 8,854 & 1.64 & 222 & 0.55 & 0.68 & 0.43 & 2.16 \\
\hline Sowa & 1,999 & I & 65 & 0.12 & 0.13 & 0.12 & 3.02 \\
\hline Urban Villages $^{\mathrm{a}}$ & 193,077 & 0.87 & 16,407 & 18.15 & 17.29 & 18.98 & 4.21 \\
\hline Ngwaketse & 23,326 & 1.02 & $\mathrm{I}, 444$ & $\mathrm{I} .48$ & 1.55 & 1.41 & 2.62 \\
\hline Barolong & 11,508 & 0.96 & 754 & 0.73 & 0.74 & 0.72 & 1.33 \\
\hline $\begin{array}{l}\text { Ngwaketse } \\
\text { West }\end{array}$ & 2,111 & 1.52 & 635 & 0.13 & 0.16 & 0.1 & 6.37 \\
\hline South East & 8,413 & I.II & 679 & 0.52 & 0.57 & 0.48 & 5.03 \\
\hline Kweneng & 13,202 & 0.96 & I,397 & 0.84 & 0.85 & 0.83 & 2.65 \\
\hline Kweneng West & 2,387 & 1.12 & 621 & 0.15 & 0.16 & 0.14 & 2.15 \\
\hline Kgatleng & $|7,57|$ & 1.38 & 1,258 & I.II & I.34 & 0.9 & 2.89 \\
\hline
\end{tabular}




\begin{tabular}{lccccccc}
$\begin{array}{l}\text { Central } \\
\text { Serowe }\end{array}$ & 19,435 & 1.04 & 1,048 & 1.24 & 1.31 & 1.18 & 1.6 \\
$\begin{array}{l}\text { Central } \\
\text { Mahalapye }\end{array}$ & 11,140 & 1.03 & 1,503 & 0.71 & 0.74 & 0.67 & 2.99 \\
$\begin{array}{l}\text { Central } \\
\text { Bobonong }\end{array}$ & 18,055 & 1.07 & 1,421 & 1.14 & 1.22 & 1.05 & 3.68 \\
$\begin{array}{l}\text { Central Boteti } \\
\text { Central }\end{array}$ & 7,716 & 1.11 & 886 & 0.48 & 0.53 & 0.44 & 3.11 \\
$\begin{array}{l}\text { Tutume } \\
\text { North East }\end{array}$ & 25,037 & 0.95 & 2,048 & 1.62 & 1.64 & 1.6 & 2.47 \\
$\begin{array}{l}\text { Ngamiland } \\
\text { South }\end{array}$ & $6,14,943$ & 0.93 & 1,096 & 1.01 & 1.01 & 1.01 & 2.04 \\
$\begin{array}{l}\text { Ngamiland } \\
\text { West }\end{array}$ & 5,440 & 0.64 & 1.113 & 0.35 & 0.28 & 0.41 & 2.11 \\
Chobe & 2,198 & 1.86 & 426 & 0.14 & 0.18 & 0.09 & 4.18 \\
$\begin{array}{l}\text { Ghanzi } \\
\text { Kgalagadi }\end{array}$ & 5,927 & 1.05 & 405 & 0.37 & 0.39 & 0.35 & 2.51 \\
$\begin{array}{l}\text { South } \\
\text { Kgalagadi }\end{array}$ & 1,703 & 1.2 & 234 & 0.11 & 0.12 & 0.09 & 1.25 \\
$\begin{array}{l}\text { North } \\
\text { Total }\end{array}$ & 3,363 & 1.1 & 149 & 0.21 & 0.23 & 0.19 & 1.86 \\
\hline
\end{tabular}

Apart from 'urban' villages, Gaborone remained the single most attractive district in the country with an in-migration rate of 8.7 percent (See Table I). Being the most developed district, 72 percent of Gaborone's population were internal migrants and immigrants. This shows that the economic and social centrality makes Gaborone the preferred destination of all migrants. Francistown had the second highest rate of in-migration (3.I percent) by 2006. Selibe Phikwe and Central Tutume were the third and fourth most attractive districts for inmigration. The least attractive district was Kgalagadi South. Due to its arid conditions and poor environmental conditions, the district had net inmigration of I,469 people only. Almost two-thirds of the out-migrants from Kgalagadi South $(5,790)$ went to urban villages, 8 percent went to the cities (Gaborone and Francistown) and 2 percent went to other towns. But other districts lost even more than they gained. For Central Serowe, for instance, the net volume of migration was $-8,357$ (i.e. there were 28,814 inmigrants and 37,17 I out- migrants).

Though the sex ratio of in-migrants was low (0.96), there were variations amongst the district level ratios. Table I shows an excess of females among people who migrated to Gaborone, Francistown, Lobatse and Orapa. Migration to urban villages was also dominated by females. Meanwhile, males were clearly the majority of those who went to Selibe Phikwe, Jwaneng and Sowa. Males also surpassed females among rural villages bound migrants. Seventyfour percent of the rural villages attracted more males than females. Only in four (out of 19) rural districts did females dominate. These are Kweneng, Central Tutume, North East and Ngamiland West (with the lowest sex ratio).

Ngwaketse West District had the highest out-migration rate (6.4 percent) among all census districts in the country. Meanwhile, Kgalagadi North seems 
to have the lowest potential to send migrants to other parts of the country. Among the townships, Lobatse had the highest rate of out-migration (5 percent).

\subsection{Preference indices}

So far, we have considered the absolute volumes of mobility and crude migration rates. But the number of people who are 'able' to leave any given area is obviously limited by the number of people living there or the so-called demographic pressure. Conversely, a migratory flow into an area of destination depends on the size of the population already residing in that area as well. If one wants to take these structural limitations into account, a significant migratory flow will have to be defined in terms of:

(i) The number of people actually moving out of the area relative to the number 'able' to migrate, and

(ii) The number of people moving into an area of destination relative to the number already living there.

A measure which reflects this is sug- gested by Shryock and Siegal (1973) and is called the Preference Index. It is formulated as below:

$$
P \cdot I=\frac{M_{i j} \times 100}{M\left(\frac{P_{i}}{P} \times \frac{P_{j}}{P}\right)}
$$

Where:

$M_{i j}=$ The number of migrants from area $i$ to $j$

$M=$ Total migrants in the country.

$P_{i}$ and $P_{j}=$ Mid-interval population of area $i$ and area $j$ respectively.

$\mathrm{P}=$ Total mid-interval population of the country.

An index of $<100$ signifies that an area (region) is under-chosen, and vice versa if the index is $>100$. The P.I. is useful as:

(i) A 'comparative' measure of assessing the importance of individual migratory flow from, or to, an area vis-à-vis that of others, and

(ii) An index of relative population concentration.

As an illustration of the index, we have attempted to compute a few index values using the lifetime migration flow data for Botswana.

Preference index for Gaborone to Francistown migration flow is computed as follows:

$$
P \cdot I=\frac{1966 \times 100}{\frac{85107}{18733661} \times \frac{59962}{18733661} \times 447160}=302
$$

Similarly, the preference index for Francistown to Gaborone flow is:

$$
P \cdot I=\frac{5361 \times 100}{\left(\frac{85107}{18733661} \times \frac{59962}{18733661}\right) \times 447160}=824
$$


Again, the preference index for Southern district to Northeast is:

$$
P \cdot I=\frac{184 \times 100}{\left(\frac{197830}{18733661} \times \frac{79863}{18733661}\right) \times 447160}=9.1
$$

Northeast to Southern district flow:

$$
P \cdot I=\frac{81 \times 100}{\left(\frac{197830}{18733661} \times \frac{79863}{18733661}\right) \times 447160}=4.0
$$

Similarly, Preference indices for some other movements are computed as follows.

Small towns to Southern district: 1027.7

Southern district to Small Towns: I527.3

Southeast to Small Towns: 1369.8

These index values show that Francistown, Gaborone, Southern district and Small Towns are over-chosen for in-migration in relation to the place of origin, whereas Northeast is underchosen. As mentioned earlier, these indices are a function of the relative population sizes of places origin and destination only. Of course, the propensity to migrate depends on several other factors; socio-economic, political and cultural.

Now we turn to the main focus of this study, i.e. the structural patterns of migration flows.

\section{Structural patterns of migration flows - Log-linear modeling}

A two-dimensional contingency table analysis through log-linear modeling has been performed here to delineate the underlying structure of migration flow matrices for Botswana. As a pre-requisite, a brief exposition of the model formulation is felt in order here.

\subsection{Log-linear model: theory}

The log-linear modeling, as a technique of multivariate analysis, is not new in demographic analysis. However, it has gained fresh impetus since 1970 for the analysis of multi-dimensional cross-classified date (Little 1978, 1980; Little and Pullum 1979; Clogg 1980, among others).

The current formulation of the loglinear model is by Birch (1963) and resembles the ANOVA model. The model may be formulated in two equivalent forms: additive and multiplicative. The additive formulation resembles closely the ANOVA paradigm. The questions for which the data were designed to answer may be stated in terms of the parameters of the model that is, the quantification of the various 'effects'. Let us formulate the model for a two-dimensional case.

If we consider the hypothesis that two variables ( $\mathrm{Pi}$ and $\mathrm{Pj}$ ) are independent, then, from probability theory, we have:

$\mathrm{P}_{i j}=\mathrm{P}_{i}, \mathrm{P}_{\mathrm{j}}$

where $P_{i j}=m_{i j} / N$

and $\mathrm{P}_{i},==\left(\mathrm{m}_{i} \cdot / \mathrm{N}\right)$ and $\mathrm{P}_{\mathrm{.j}}=\left(\mathrm{m}_{. j} / \mathrm{N}\right)$

or $m_{i j} / \mathrm{N}=\left(\mathrm{m}_{i} / \mathrm{N}\right) \cdot\left(\mathrm{m}_{\cdot j} / \mathrm{N}\right)$

or $\mathrm{m}_{i j}=\left(\mathrm{m}_{i} \cdot \mathrm{m}_{\cdot j}\right) / \mathrm{N}$

where

$m_{i j}=$ expected cell frequency and $\mathrm{N}=\mathrm{m}$.

Taking the logarithm of both sides, we 
obtain:

In $\mathrm{m}_{i j}=\ln \mathrm{m}_{i}+\ln \mathrm{m}_{\cdot j}-\operatorname{In} \mathrm{N}$.

Equation (I) may be reformulated in analogy with the ANOVA model as follows:

In $m_{i j}=U+U_{1}(i)+U_{2}(j)+U_{12}(i j)$

Where

$$
\begin{aligned}
& U=\frac{1}{I J} I_{n_{-}} m_{i j} \\
& U_{1}(i)=1 \sum_{j} I_{n} m_{i j}-U \text { for all } i \\
& U_{2}(j)=\frac{1}{I} \sum_{i} \quad I_{n_{-}} m_{i j}-U \text { for all } j \\
& U_{12}(i j)=I_{n_{-}} m_{i j-} U-U_{I}(i)-U_{2}(j)
\end{aligned}
$$

for all $i$ and $j$.

$\left(U_{12}(i j)=0\right.$ if we assume complete independence of variables or, in this study, the complete absence of push or pull factors.)

Each parameter of the model represents a particular structural effect on $\mathrm{m}_{\mathrm{ij}}$. In the additive model, the expected cell count is the sum of various effects which are mentioned below:

$U=$ overall mean effect, i.e., it is a size effect; the geometric mean of all cell counts.

$U_{I}\left({ }_{i}\right)=$ row effect or main effect on In $m_{i j}$ of the fact that variable $I$ is at level $i$. $U_{2}(j)=$ column effect/ main effect on In mij of the fact that variable 2 is at level $\mathrm{j}$.

$U_{12}(i j)=$ first order interaction effect or joint effect on In mij from levels $i$ and $j$ of variables I and 2 respectively.

The overall mean effect $(U)$ is a scaling factor. Since multiplication of all the elements of a table by a constant does not affect the structure, the interaction effects are retained. Only the parameter value of $U$ changes. For instance, if we do not consider a table of expected counts $\left(\mathrm{m}_{i j}\right)$ but a table of probabilities (Pij) where $\mathrm{Pij}=\mathrm{mij} / \mathrm{N}$, then the overall mean effect $U=U$-InN. The main effects reflect the difference between uni-variate marginal totals (row and column) and are therefore relevant for standardization and comparison of tables. The log-linear model depicted above is known as the saturated model because the number of independent parameters is equal to the number of cells in the contingency table. The main and first order effects are measured as deviations, and consequently they must obey the following constraints, as in ANOVA:

$\sum_{\mathrm{i}} \mathrm{U}_{\mathrm{I}}(\mathrm{i})=\sum_{\mathrm{j}} \mathrm{U}_{2}(\mathrm{j})=\sum_{\mathrm{i}} \mathrm{U}_{12}(\mathrm{ij})=\sum_{\mathrm{j}} \mathrm{U}_{12}(\mathrm{ij})=0$

If a parameter of the log-linear model is zero, it implies that the associated interaction does not exist. In other words, given that variables $I$ and 2 are independent, the unsaturated model $I_{n}$ $\mathrm{mij}=U=U_{1}(i)+U_{2}(j)$ fits the contingency table data perfectly (i.e. the expected cell counts mij coincide with the observed counts xij). However, it should be kept in mind that a log-linear parameter represents a particular interaction effect of the $m_{i j}$ array.

Log linear analysis is widely regarded as an extension of the twoway contingency table analysis. Nonetheless, the conditional relationship between two or more discrete, categorical variables is analyzed by taking the natural logarithm of the cell frequencies within a contingency table. Although log linear models can be used to analyze the relationship between two categorical variables (two-way contingency tables), they are more commonly used to evaluate multi-way contingency tables that involve three or more variables. The variables investi- 
gated by log linear models are all treated as "response variables". In other words, no distinction is made between independent and dependent variables.

It is demonstrated that the log linear models can be used to study the place to place migration flows within a geographic entity. They can effectively identify patterns of state affinity or disaffinity associated with social geography. It is assumed that the propensity to stay within a spatial unit reflects the extent of socio-cultural structure within the geographic boundaries, after geographic distance and population size effects are accounted for. Therefore, this propensity to stay within a place is captured by log linear parameter.

We will now present the results of the log linear modeling analysis as applied here. Table 2 shows the lifetime migration flow matrix by place of birth and place of current residence $\left(m_{i j}\right)$ for 12 districts $^{2}$ in Botswana as enumerated in Botswana Demographic Survey (CSO, 2008). The rows of the matrix represent out-migration flows and the columns in-migration flows. The right diagonal elements of the matrix represent the non-movers or stayers. The districts here appear very heterogeneous in terms of population size. When we consider place of birth, Central district has the largest population size followed by Kweneng and Southern district. On the other extreme, the lowest population size is recorded in Small Towns. The same pattern is observed for place of destination as well.

The last row and last column ( Table 3) show the proportional distribution of in-migration and outmigration flows respectively. A close scrutiny of these proportions reveals the net gains and losses of the districts in terms of migratory flows. Gaborone, being the capital city district, stands apart as the highest gainer, i.e. 4.2 percent. The other districts which gained or pulled migrants into, at least in some degrees, are Francistown (0.8\%), Towns (0.6\%), Small Towns $(0.8 \%)$, Southeast $(0.3 \%)$, Central $(0.3 \%)$ and Ghanzi \& Kgalagadi (0.2 \%). The districts Kweneng and Ngamiland have not gained or lost any population significantly. Kgatleng ( - I.9 $\%)$, Southern (-I.I \%) and Northeast ($0.9 \%)$ are the losers by way of more out-migration in relation to in-migration.

2. There are 16 administrative districts in Botswana of which a few are towns or townships. The latter are classified here as Towns and Small towns and a total of 12 districts are considered for the study for analytical convenience. 


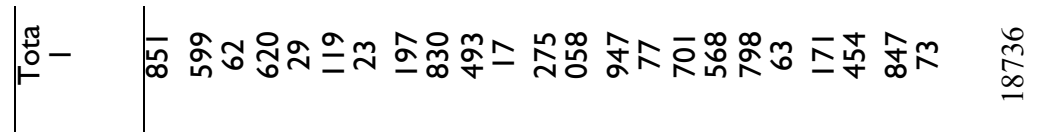

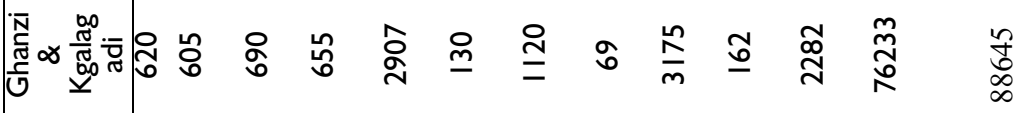

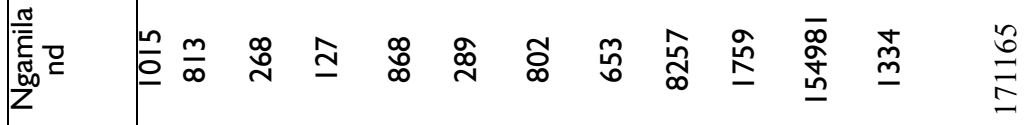

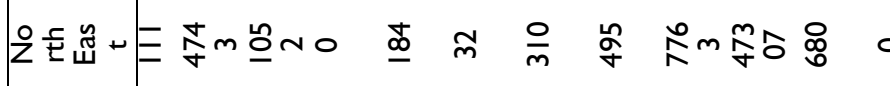

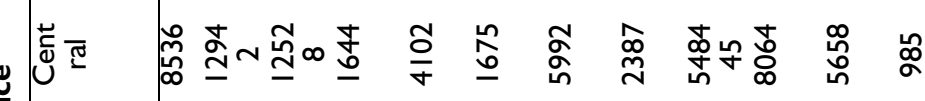
票点

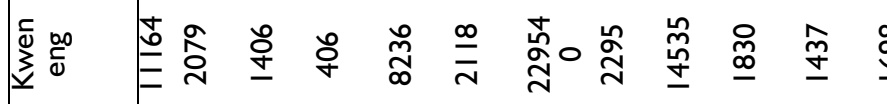

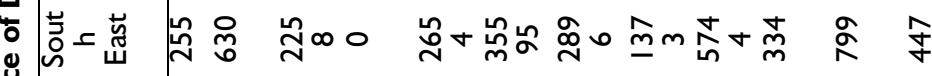

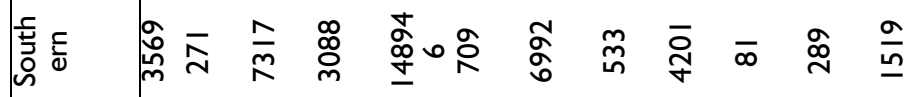

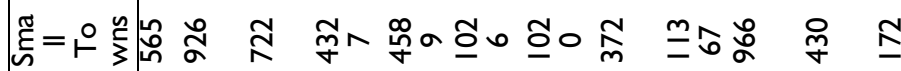

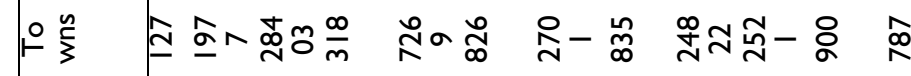

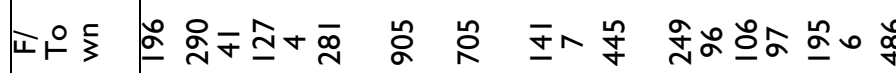


Table 3 Population of districts by origin and destination and their proportions, Botswana, 2006

\begin{tabular}{lccccc}
\hline DISTRICT & $\begin{array}{c}\text { Population } \\
\text { of origin }\end{array}$ & $\begin{array}{c}\text { Proportion } \\
(\%)\end{array}$ & $\begin{array}{c}\text { Population } \\
\text { of } \\
\text { destination }\end{array}$ & $\begin{array}{c}\text { Proportion } \\
(\%)\end{array}$ & $\begin{array}{c}\text { Net gain/ } \\
\text { loss }\end{array}$ \\
\hline Gaborone & 85107 & 4.54 & 163181 & 8.71 & 4.17 \\
F/Town & 59962 & 3.20 & 74169 & 3.96 & 0.76 \\
Towns & 62029 & 3.31 & 72637 & 3.88 & 0.57 \\
Small Towns & 11923 & 0.64 & 26483 & 1.41 & 0.77 \\
Southern & 197830 & 10.56 & 177517 & 9.47 & -1.09 \\
South East & 49317 & 2.63 & 55281 & 2.95 & 0.32 \\
Kweneng & 275058 & 14.68 & 276744 & 14.77 & 0.09 \\
Kgatleng & 94777 & 5.06 & 91204 & 4.87 & -1.90 \\
Central & 701568 & 37.44 & 612958 & 32.71 & 0.27 \\
North east & 79863 & 4.26 & 63677 & 3.40 & -0.86 \\
Ngamiland & 171454 & 9.15 & 171165 & 9.14 & -0.01 \\
Ghanzi \& Kgalagadi & 84773 & 4.52 & 88645 & 4.73 & 0.21 \\
\hline Total & 1873661 & 100.00 & 1873661 & 100.00 & \\
\hline
\end{tabular}

Table 4 shows the main results of the log-linear modeling we performed here. The cell values are the first order interaction effects between the districts and they imply the extent of push and pull factors between the districts of study. The row effects $\left(U_{I}(i)\right)$ or the overall push effects from the places of birth are given in the last column. The column effects $\left(\mathrm{U}_{2}(\mathrm{j})\right)$ or the overall pull effects into the place of destination or residence are shown in the last row. The overall mean effect $(U)$ is shown in the extreme right bottom corner.

The overall mean effect $(U)$ is 7.4. It is the size effect or the geometric mean of all migration flows and this is used as a scaling factor. The major parameters are the row, column and interaction effects. Let us first examine the row effects implying the overall push effects from the places of birth. The Central district has the highest row effect ( 2.2) implying the highest push effect among all the districts considered. It has pushed the largest number of people to move out and reside in other districts. From the interaction effects, we observe that Northeast and Francistown had been the most attractive places of destination for the movers from Central region $\left(U_{12(i j)}=1.0\right.$ and 0.4 respectively). The other districts which pulled migrants from Central district are Towns and Small towns. Next, Southern and Kweneng districts have the highest push factors (0.72 and 0.7I respectively). Again, Small Towns and Towns are gainers from Southern district and Kgatleng, Southern and Southeast are the gainers from Kweneng outmigrants. It is interesting to note that although Gaborone is the highest net gainer of in-migrants in the country, it also exhibited a significantly high push effect, implying a greater mobility among those born in Gaborone. 


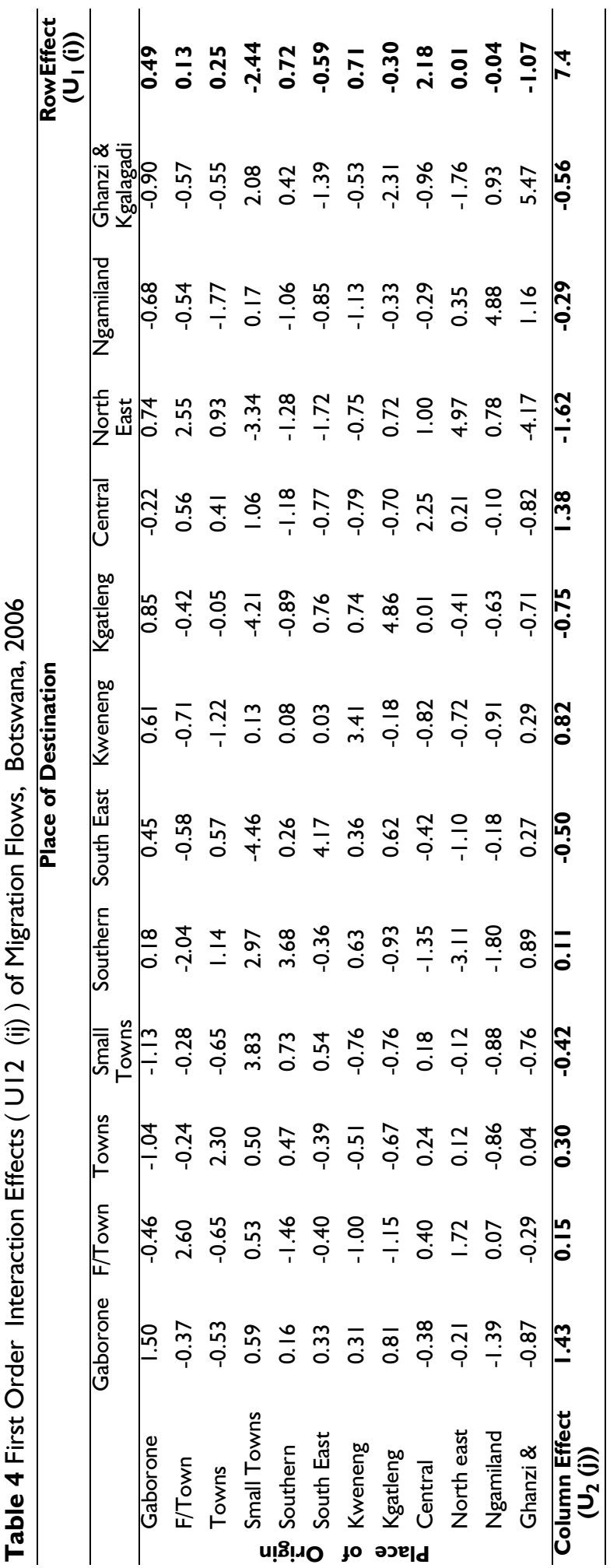


Let us now turn to the column effects $\left(U_{2(j)}\right)$ or the pull effects for the places of residence. Gaborone has the highest column effect (I.43) followed closely by Central district (1.38). So far as Gaborone is concerned, five other districts show positive interaction effects of which Kgatleng $(0.8 \mathrm{I})$ and Small Towns ( 0.59 ) seem to be the major contributors. Nagamiland and Ghanzi \& Kgalagadi have the highest negative interaction effects with Gaborone, most likely a reflection of physical distance. As regards the Central district, four districts - Small Towns, Francistown, Towns and Northeast, show positive interaction effects. Small Towns have the largest share of positive interaction implying a higher flow from there to Central district.

North East exhibits the lowest negative column effect (-I.62) followed by Kgatleng, Ghanzi \& Kgalagadi and Southeast in that order. Northeast has the highest negative interaction with Ghanzi \& Kgalagadi, followed by Small Towns, Southeast and Southern districts; again, perhaps, a reflection of distance between the districts. When we consider Kgatleng, Small Towns has the highest negative interaction effect followed by Southern, Southeast and Ghanzi \& Kgalagadi districts. So far as Ghanzi \& Kgalagadi is concerned, Central, Northeast, and Southeast have large negative interaction effects implying lesser propensity to move to Ghanzi \& Kgalagadi. When we move to Southeast, Small Towns show an unusually high negative preference (-4.46) followed by Northeast, Francistown and Central districts.

If we consider the interaction effects as a measure of attraction or repulsion, Small Towns and Southern districts show attraction of the highest magnitude followed by Francistown \& Northeast, and Small towns and Ghanzi \& Kgalagadi. The degree of repulsion is seen highest between Southeast \& Small towns followed by Kgatleng \& Small towns and Northeast, Ghanzi \& Kgalagadi.

\section{Summary and conclusions}

Among the total population, 40 percent are life time migrants within Botswana. Among the internal migrants, females exceed males, with the sex ratio being 0.91 . Movement from rural to urban areas still dominates the pattern of internal migration in Botswana. Fortyfive percent of all movements were from rural to urban areas. Gaborone, the capital city, received the highest volume of inmigrants and immigrants; 72 percent of Gaborone's population is internal migrants. This is quite understandable since Gaborone could be singled out for infrastructure development in the country. This high attractiveness of the capital city is not viewed as a positive sign and calls for the speedy development of other major urban centres such as Francistown, Palapye, Lobatse and Maun which will enable a better redistribution of population. Francistown had the second highest rate of inmigration (3.I percent) and the least attractive district is Kgalagadi South. There is ample scope for the development of Kgalagadi region since it provides tremendous tourism potential.

A total of 12 districts were selected for the analysis which does not show any similarity in terms of population size. When we consider place of birth, Central district has the largest popula- 
tion size, followed by Kweneng and Southern district. On the other extreme, the lowest population size is recorded in Small Towns. The same pattern is observed for place of destination as well. In terms of net gains and losses, the other districts which gained or pulled migrants into, at least in some degrees, are Towns $(0.6 \%)$, Small Towns (0.8\%), Southeast $(0.3 \%)$,Central $(0.3 \%)$ and Ghanzi \& Kgalagadi (0.2 $\%)$. The districts Kweneng and Ngamiland have not gained or lost any population significantly. Kgatleng (-I.9\%), Southern (-I.I \%) and Northeast (-0.9 $\%)$ are the losers by way of more outmigration.

The main results of the log-linear modeling are as follows. The Central district has shown the highest push effect. From the interaction effects, we observe that Northeast and Francistown had been the most attractive places of destination for the movers from this area. The other districts which pulled migrants from Central region are Towns and Small towns. Next, Southern and Kweneng districts have the highest push effects. Again, Small Towns and Towns are the gainers from Southern district and Kgatleng. Southern and Southeast are the gainers from Kweneng out-migrants. It is interesting to note that although Gaborone is the highest net gainer in the country, it also exhibited a significantly high push effect, implying a greater mobility among those born in Gaborone.

Let us now turn to the pull effects at the places of residence. Gaborone has the highest column effect followed closely by Central district. So far as Gaborone is concerned, five other districts show positive interaction effects of which Kgatleng and Small Towns seem to be the major contributors. Ngamiland and Ghanzi \& Kgalagadi have the highest negative interaction effects with Gaborone, perhaps a reflection of physical distance. As regards the Central district, four districts - Small Towns, Francistown, Towns and Northeastcarry positive interaction effects. Small Towns have the largest share of positive interaction implying a higher flow from there to Central district.

North East exhibits the lowest negative column effect followed by Kgatleng, Ghanzi \& Kgalagadi and Southeast in that order. When we consider Kgatleng, Small Towns has the highest negative interaction effect followed by Southern, Southeast and Ghanzi \& Kgalagadi districts.

If we consider the interaction effects as a measure of attraction or repulsion, Small Towns and Southern districts show attraction of the highest magnitude followed by Francistown Northeast, Small towns and Ghanzi \& Kgalagadi. The degree of repulsion is seen highest between Southeast \& Small towns followed by Kgatleng \& Small towns and Northeast \& Ghanzi \& Kgalagadi. By and large, the districts which have registered higher push factors are the under developed regions in the country relatively. Of late, Botswana has launched a long term programme of sustained economic diversification. This should enable infrastructure development and creation of job opportunities in those areas where push factors are higher. The policy on industrial location should also be driven by the pull and push factors observed here.

Finally, we could not go into the 
determinants of the various effects studied here due to the non-availability of data in the present study and hence further studies are needed for this.

\section{Acknowledgements}

We thank the anonymous referees for their valuable comments for revising the manuscript.

\section{References}

Adepoju A. 1983 "Issues in the study of migration and urbanization in Africa south of the Sahara, Population movements: their forms and functions in urbanization and development", P. A. Morrison. Liège, Ordina - IUSSP, Pp. II5-I49.

Adepoju, A. 2004, "Regional Migration Processes, Multilateral and Bilateral Migration Agreements in SubSaharan Africa", International Organisation for Migration: Berne Initiative Policy Research Papers, IOM, Berne.

Adepoju, A. 2005a, "Review of Research Data on Trafficking in SubSaharan Africa", International Migration, Vol. 43, Nos. I \& 2.

Adepoju, A. 2005b "Patterns of Migration in West Africa" in Manuh, T. (Ed) At Home in the World? International Migration and Development in Contemporary Ghana and West Africa. Accra: SubSaharan Publishers.

Andersson, A. 200I "Reinterpreting the Rural-Urban Connection: Migration Practices and Socio-Cultural Dispositions of Buhera Workers in Harare", Journal of the International African Institute, Cambridge University Press.
Beauchemin, C and Bocquier, 2004; "Migration and Urbanization in Francophone West Africa: An Overview of the Recent Empirical Evidence", Urban Studies, Vol 4I, No I I, Pp 2245-2272.

Becker C.M., Hamer A.M. ,1994, Beyond urban bias in Africa: urbanization in an era of structural adjustment, Portsmouth - London.

Bilsborrow R.E. (ed.), 1998, Migration, Urbanization, and Development: New Directions and Issues, United Nations Population Fund (UNFPA), NewYork.

Birch, M. (1963): “Maximum Likelihood in Three-Way Contingency Tables,"Journal of The Royal Statistical Society, Vol. 25, pp.220223

Bocquier, 2004, "Analyzing urbanization in sub-Saharan Africa", in Champion, $A$ and $G$ Hugo (editors), New Forms of Urbanization: Beyond the UrbanRural Dichotomy, Ashgate, PpI33150.

Brockerhoff, 1998, "Migration and the Fertility Transition in African Cities", in R.E. Bilsborrow, Migration, Urbanization, and Development: New Directions and Issues, United Nations Population Fund (UNFPA), NewYork, Pp. 357-390.

Clogg, C.C., 1980: "Measuring Unemployment: Demographic Indications for the United States, Academic Press, New York.

Crush, J., Campbell, E.K., Green, T., Simelane, H. and Nangulah, S., 2006. "States of vulnerability: the future brain drain of talent to South Africa", Southern African Migration Project, Migration Policy Series 42. Cape Town. 
Campbell, E.K and Oucho, JO, 2003. "Changing attitudes to immigration and refugee policy in Botswana", Southern African Migration Project, Migration Policy Series 28. Cape Town.

C.S.O , 2008, Botswana Demographic Survey, 2006, Central Statistical office, Government of Botswana, Gaborone.

C.S.O, 201I, Population \& Housing Census - Preliminary Results Brief, Central Statistical office, Government of Botswana, Gaborone.

Deborah Potts, 2009, "The slowing of sub-Saharan Africa's urbanization: evidence and implications for Urban livelihood", Environment and Urbanization, 21: 253.

Dijk, H.V.. Dick Foekan and Kiky van Til, 200I, "Population Mobility in Africa: An Overview" in Mobile Africa: Changing patterns of Movement in Africa and Beyond. Mirjam De Bruijn, Rilk Van Dijk and Dick Foekan (eds.), Boston, USA.

Gurmu, E., Sidney Goldstein and Alice Goldstein, 2000, "Migration, Gender and Health Survey in Five Regions of Ethiopia”, Brown University, USA. (Mimeo)

Goldstein, S., 1976, "Facets of Redistribution, Research Challenges and Opportunities, Demography, Vol. 13, pp.423-34.

Little, R.J.A., 1978, "Generalized Linear Models for Cross Classified Data from the WFS", Technical Bulletin 5, World Fertility Survey, London.

Little, R.J.A., 1980, "Linear Models from WFS Data", Technical Bulleting 9, World Fertility Survey, London.

Little, R.J.A. and T.W. Pullum, 1979,
"The Generalized Linear and Direct Standardization

- A Comparison" Sociological Methods and Research, 7, pp.475-50I.

Massey et al., 1993, "A Validation of the Ethnosurvey: The Case of MexicoU.S. Migration", International Migration Review, Vol. 34, No. 3.

Masukusuku, T.M, 20II, "Structural Patterns of Spatial Mobility in Botswana: Application of Mathematical Models", M.A dissertation (unpublished), Department of Population Studies, University of Botswana.

Mberu, B.U., 2006, “ Internal migrants and household living conditions in Ethiopia". Demographic Research, I4(2I), 509-540.

Mberu, B. U. and Pongou, R., 2005, Internal Migration and Household Living Conditions in Ethiopia, APHRC Working Paper No. 31 .

Nair, P.S., 1982, India's Population: A multi-regional demographic Analysis, Working Paper 35, NIDI, Voorburg, The Netherlands.

Nair, P.S, 1985, "Estimation of Period specific gross migration flows from limited data: Bi-proportional Adjustment approach', DEMOGRAPHY, U.S.A, Vol. 22, No. I, Pp. I33-I 43.

Nair, P.S., 1985, "Interstate period migration in India, |97|-198I, DEMOGRAPHY - INDIA, Vol. I4, No. 3, New Delhi, pp. 417- 432.

Nair, P.S., 1984, "Levels and Structure of inter-regional migration flows in India, 197I" JANASAMKHYA, University of Kerala, 2[I], Pp. 18-33.

Nair, P.S., 1983, 'Structural Patterns of Internal Migration in India and Sri Lanka: Log-Linear modeling approach' in K. Srinivasan and S. 
Mukerji [Eds] Dynamics of Population and Family Welfare, Himalaya Publishers, Bombay. Pp. 123-I42.

Oucho, J.O, 1998, "Regional integration and labour mobility in Eastern and Southern Africa". in R Appleyard (ed), Emigration dynamics in developing countries, Vol I.SubSaharan Africa, Sydney: Ashgate Publishing.

Oucho, J.O., 2002, "Skilled immigrants in Botswana: stable but temporary work force". in D.A McDonald and J Crush (eds), Destinations unknown. Pretoria: Africa Institute of South Africa and Kingston, Ontario: Southern African Migration Project, pp 157-179.

Oucho, J.O., 2006, "Cross-border migration and regional initiatives in managing migration in southern Africa. In P. Kok, D. Gelderblom, J.O. Oucho and J van Zyl (eds), Migration in South and southern Africa. Pretoria: HSRC Press, pp 4770.

Shyrock, H.S. and J.S. Seigal, 1973, The Methods and Materials of
Demography, U.S. Bureau of the Census, Washington.

Todaro, M., 1997, “Urbanization, unemployment and migration in Africa: theory and policy", Population Council, New York.

United Nations, 1967, Population distribution and Internal Migration, New York, Mimeo.

UN-HABITAT., 2003, The Challenge of Slums: Global Report on Human Settlements. London and Sterling: Earthscan.

Willekens, F., 1977, "The Recovery of Detailed Migration Patterns from Aggregate Data: An Entropy Maximizing Approach", R.M. 77-58, I.I.A.S.A., Luxemburg, Austria.

Willekens, F., 1983, "Identification and Measurement of Spatial Population Movements, ESCAP, Bangkok.

Willekens, F. and P.S. Nair, I98I, "The Data Base of Migration Analysis in Developing Countries: with Emphasis on India", Working Paper 28, NIDI, Voorburg, The Netherlands. 